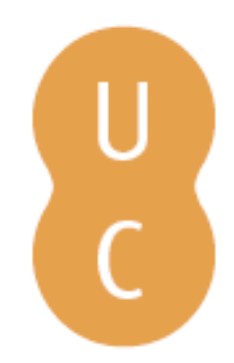

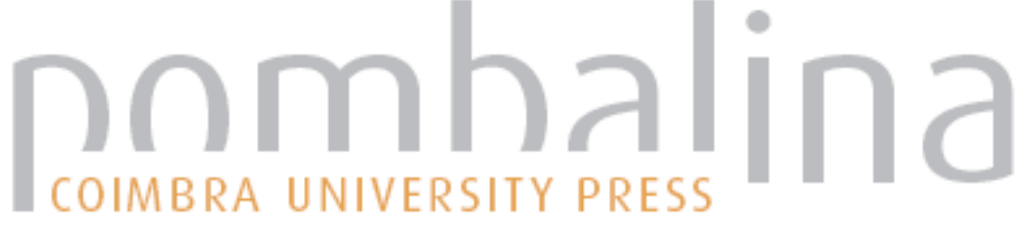

\section{Development of multilingual network resource for comparative-contrastive dictionary of fire science terminology}

Autor(es): $\quad$ Sofronova, Tatiana M.; Volokitina, Alexandra V.

Publicado por: Imprensa da Universidade de Coimbra

URL

persistente: URI:http://hdl.handle.net/10316.2/44624

DOI: $\quad$ DOI:https://doi.org/10.14195/978-989-26-16-506_107

Accessed : $\quad$ 26-Apr-2023 10:30:18

A navegação consulta e descarregamento dos títulos inseridos nas Bibliotecas Digitais UC Digitalis, UC Pombalina e UC Impactum, pressupõem a aceitação plena e sem reservas dos Termos e Condições de Uso destas Bibliotecas Digitais, disponíveis em https://digitalis.uc.pt/pt-pt/termos.

Conforme exposto nos referidos Termos e Condições de Uso, o descarregamento de títulos de acesso restrito requer uma licença válida de autorização devendo o utilizador aceder ao(s) documento(s) a partir de um endereço de IP da instituição detentora da supramencionada licença.

Ao utilizador é apenas permitido o descarregamento para uso pessoal, pelo que o emprego do(s) título(s) descarregado(s) para outro fim, designadamente comercial, carece de autorização do respetivo autor ou editor da obra.

Na medida em que todas as obras da UC Digitalis se encontram protegidas pelo Código do Direito de Autor e Direitos Conexos e demais legislação aplicável, toda a cópia, parcial ou total, deste documento, nos casos em que é legalmente admitida, deverá conter ou fazer-se acompanhar por este aviso.

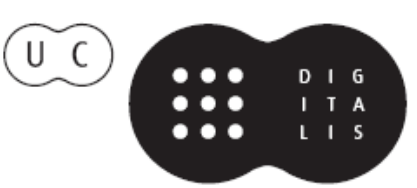




\section{ADVANCES IN}

\section{FOREST FIRE RESEARCH}

\section{8}

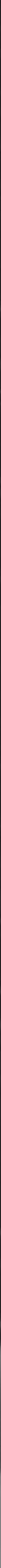




\title{
Development of multilingual network resource for comparative- contrastive dictionary of fire science terminology
}

\author{
Tatiana M. Sofronova ${ }^{1}$; Alexandra V. Volokitina ${ }^{2}$ \\ 1*Astafiev Krasnoyarsk State Pedagogical University, ul. A. Lebedevoy,89, Krasnoyarsk 660049, \\ Russia, \{tmsofronova@gmail.com*\} \\ ${ }^{2}$ Sukachev Institute of Forest SB RAS, ul.Akademgorodok,50/28, Krasnoyarsk 660036, Russia, \\ \{volokit@ksc.krasn.ru\}
}

\begin{abstract}
Our ambition is to obtain experience in terminology management of large international lexicographic projects through cooperation with the international terminology and lexicography experts and to improve the software for implementation of the concept of the multilingual network resource for a comparativecontrastive dictionary of fire science terminology (on the example of English and Russian). Since the project implementation requires international team efforts for its logical completion, Tatiana M. Sofronova (being both a terminologist and a fire scientist) would like to become a uniting, organizing and conceptual link in promotion of this international project and to earn the support of recognized international experts in Lexicography and Terminology Management.

The project goal is development of a multilingual network resource for a comparative-contrastive dictionary of fire science terminology (FST) at the high modern technological level. This dictionary is meant to: 1) combine features of translation, explanatory, encyclopedic, ideographic and student's dictionaries; 2) help to treat each national FST with care preserving the uniqueness of each system of knowledge; 3) enable comparison of different countries' scientific terminologies for their harmonization (at the level of systems through terminology comparison and at the level of individual terms through terminology contrasting); 4) suggest joint ways of solving translation issues by terminology translators and fire science experts; 5) reflect diachronic development of a scientific notion behind a term and existing approaches to its explanation; 6) be open for updating and editing; 7) provide potential involvement of FSTs from different languages and countries to this project.

The main project objectives include: 1. Obtaining theoretical experience in management of large international terminological projects through collaboration with leading international experts in the field of terminology and lexicography. 2. Improving the software for the multilingual network resource aimed at development of a comparative-contrastive fire science dictionary on the basis of the elaborated prototype of the bilingual fire science glossary. 3. Preparing relevant project documents for the implementation of the multilingual network resource for the comparative-contrastive fire science dictionary that could clearly guide efforts of fire scientists and translators/terminologists in different countries.
\end{abstract}

Keywords: network resource, terminological lexicography, multilingual modeling, fire science terminology

\section{Background}

It is known that the issues of lexicographical modeling of bilingual and multilingual terminological dictionaries occupy a special place in the wide range of terminological and lexicographical works (Tabanakova et al., 2009). However, none of the studies individually, or their combination can claim to be a complete and universal scheme of stages of work on a dictionary, in each case, project development should take into account special features of a terminology, requirements of potential users, and working conditions (Kudashev, 2007).

The theory and practice of modern terminological lexicography attaches a great importance to contrastive descriptions of the meanings of words from different semantic categories and different

Advances in Forest Fire Research 2018 - Page 980 
languages (see: Sternin, 2007). Among recent works in this direction is A.M. Bobunov's contrastive dictionary of Russian and English language folk songs (2012). Such dictionaries are valuable for contrastive presenting of non-terminological words, since creation of a contrastive dictionary of scientific terminology requires systematic analysis of interlingual terms and scientific concepts behind them both at the level of comparable subsystems (comparison), and at the level of parallel pairs of terms (contrasting). This dictionary should be focused not only on the linguistic, but also on the extralinguistic information, on how scientists perceive the world through the prism of scientific concepts.

Of paramount importance is lexicographic description of young terminologies, which have developed their distinctive features in different countries and scientific schools and have never been subjected to linguistic research. Among them is fire science terminology (FST). Having originated from the depths of the forest management terminology in the middle of the XX century. To date, the basic research in the field of FST is carried out and summarized in the monograph Lexicographical modeling of Russian and English fire science terminology (Felde, Sofronova, 2017), and is published in eight peer-reviewed papers.

As a result of Sofronova's training in Environmental Sciences at the University of Montana and the Missoula Fie Lab within the Fulbright Faculty Development Program (2008-2009), she developed an electronic prototype of a comparative-contrastive bilingual fire science glossary (Russian state registration number 0321201925), established contacts with the leading specialists in the US and Russian fire science, and defended her $\mathrm{PhD}$ thesis on the fundamentals of lexicographic modeling of Russian and English fire science terminology at the Tyumen State University (Russia, 2013).

\section{Problematic}

When considering the history of the formation of Russian and English FST we distinguished three similar stages in its development (Sofronova, 2008) and concluded that the modern fire science is at an extraordinary stage of development (Kuhn, 1962). The latter implies unwanted terminological confusion as a result of distinctive terminology development in different countries, in different scientific schools, thus preventing mutual understanding of scientists from different scientific schools and countries. Therefore, coordination and harmonization of terms and notions is a long overdue problem in the modern fire science.

When disclosing the degree of order in modern FST, we have found that this terminology is poorly ordered and poorly harmonized (Sofronova, 2010). The Russian terminology faces the following issues: (a) absence of fire science dictionaries; (b) low quality of state standards on fire management terminology (e.g., lack of coordination in the extraction of generic terms, variability in definitions, erroneous definitions). The English terminology is characterized by: (a) absence of formal ideographic dictionaries in Fire Science; (b) national specific features of the English FST in the United States, Canada and Australia. Harmonization of the Russian and English FST is interfered by poor quality of translation dictionaries, which is proved by: a) partial cover of fire science terms in forestry dictionaries (Filipchuk, 2002; Rodin, Filipchuk, 2006; Helms, 1998); b) presence of artificial translation equivalents (International multilingual fire management terminology, www.fire.unifreiburg.de); c) presence of several translations of a term without disclosing their distinguishing features and presence of terms with erroneous translations (Mozhaev et al., 1998). This situation is due to disparity of the Russian and English terminological fields, which is caused by unique national term formation, variability in understanding of terms by different scientists and scientific schools and misleading terms. Mechanical comparison of terminological systems with unique segmentation of the area of knowledge only increases terminological confusion (as an example, see FAO/ GFMC ..., 2003). In 2006-2007, scientists of the St. Petersburg Research Institute of Forestry in collaboration with Canadian colleagues attempted to harmonize the Russian and English FST, but the results of their 
work remained unpublished. In 2012, European scientists created an English-language European Wildfire Glossary, which is a mixture of different terminologies of European countries and is suitable mainly for practitioners working at the international level. For scientists, every scientific term is associated with a specific terminological system, and scientific concepts do not remain static over time. Therefore, this confusion of terminologies can only hinder the development of the scientific thought.

\section{Specific aim and Objectives}

The project specific aim is development of a multilingual network resource for a comparativecontrastive dictionary of fire science terminology (on the example of English and Russian) at the high modern technological level. This dictionary is meant to: 1) combine features of translation, explanatory, encyclopedic, ideographic and student's dictionaries; 2) help to treat each national fire science terminology with care preserving the uniqueness of each system of knowledge; 3) enable comparison of different countries' scientific terminologies for their harmonization (at the level of systems through terminology comparison and at the level of individual terms through terminology contrasting); 4) suggest joint ways of solving translation issues by terminology translators and fire science experts; 5) reflect diachronic development of a scientific notion behind a term and existing approaches to its explanation; 6) be open for updating and editing; 7) provide potential involvement of fire science terminologies from different languages and countries to this project.

The main project objectives include: 1 . Obtaining theoretical experience in management of large international terminological projects through collaboration with leading international experts in the field of terminology and lexicography. 2. Improving the software for the multilingual network resource aimed at development of a comparative-contrastive fire science dictionary on the basis of the elaborated prototype of the bilingual fire science glossary. 3. Preparing relevant project documents for the implementation of the multilingual network resource for the comparative-contrastive fire science dictionary that could clearly guide efforts of fire scientists and translators/terminologists in different countries.

\section{Significance}

Prior to our research, the terminology of forest fire science had never been involved in the linguistic studies and had never been subjected to systematic comparative and lexicographical analysis. Russia has no special dictionaries in this field of knowledge yet. There are only general reference materials on forestry and forest management covering the FST only partially. The first brief glossary of fire science terms was published by Prof. N.P. Kurbatskiy in the 1972 collection of articles. The US, on the contrary, have official glossaries of fire management terminology, which, however, do not always reflect the modern development of the scientific thought in the field of fire science (Glossary ..., 1990; Glossary ..., 2007). In 2007, a US electronic fire science glossary FireWords (Scott, Reinhardt, 2007) was created. It was aimed at clarifying understanding of 300 fire science terms. Unfortunately, the work on the project was terminated for financial reasons, and about $25 \%$ of the terms were not provided with glossary entries, but the results of this work were published on the website: http://www.firewords.net/. During my Fulbright training, the authors of the FireWords kindly provided the accumulated material as a legacy and software for use in the prototype of the bilingual glossary of the Russian and US FST.

The theoretical significance of our study lies in realization of the strategy for comparativecontrastive lexicographic modeling of the dynamically evolving terminology of a relatively young fire science that is a definite contribution to the theory of bilingual (and potentially, multilingual) terminological lexicography. The strategy of the proposed network resource modeling makes it possible to disclose the variability in understanding of terms by different scientists and scientific 
schools, to correct or logically synthesize definitions, leaving a user the right to their own conclusions in the analysis of the discussion section in the dictionary entry.

The practical importance of the project lies in the versatility of the lexicographical product being developed that may be addressed to fire scientists, translators/interpreters, and students of forestry departments majoring in forest fire protection. Development of the multilingual dictionary of fire science terms and concepts systematized within a language / country and harmonized among languages /countries should improve mutual understanding and exchange of information and experience among scientists of different countries, and also should help involve them in the process of systematization of their national terminology and in the discussion of problematic aspects of its harmonization with the terminology of other countries. As a result, such an electronic resource may become the basis for a large international project on development of a multilingual network resource on similar informational and technological but more rigorous scientific principles as Wikipedia or Wiktionary. Creation of such a dictionary should facilitate (and, possibly, automate, to some extent) translation of scientific works, which remain untranslated or poorly translated.

\section{Methodology}

Creation of any bi- or multilingual lexicographical product involves comparative and contrastive studies. They are based on the general principles of terminology analysis such as the principles of comparability, consistency, sequence of analysis of a linguistic material. Their main difference lies in the level of description of the object of study and the sequence of comparison: comparative analysis is conducted at the level of subsystems, fields, groups, independently with the following comparison, and contrastive analysis is conducted at the level of individual terminological units in the direction from a unit of one language to its possible correspondences in other languages (Sternin, 1992).

Effective semantization of scientific terms in the dictionary and transfer of the accumulated scientific experience with the preservation of national terminological peculiarities is possible through realization of the algorithm, the key elements of which are: a) terminological system modeling through comparable logical-conceptual schemes; b) diachronic analysis of the development of scientific concepts in dictionary entries and synthesis of definitions based on the accumulated scientific expertise; c) translation commentary which takes into account the current scope of the term concept in multilingual terminological systems and offers a contrastive analysis of relative term equivalents or suggests artificial equivalents in case of non-equivalent terminology.

The prototype of the comparative-contrastive bilingual electronic glossary of the Russian and US FST (Fig. 1 and 2) developed according to the algorithm will serve as a stepping stone for the realization of a multilingual network resource for fire science dictionary. This dictionary will combine the parameters of translation, explanatory, encyclopedic, ideographic and student's dictionaries and should be a means of harmonization of the FST among different languages and countries.

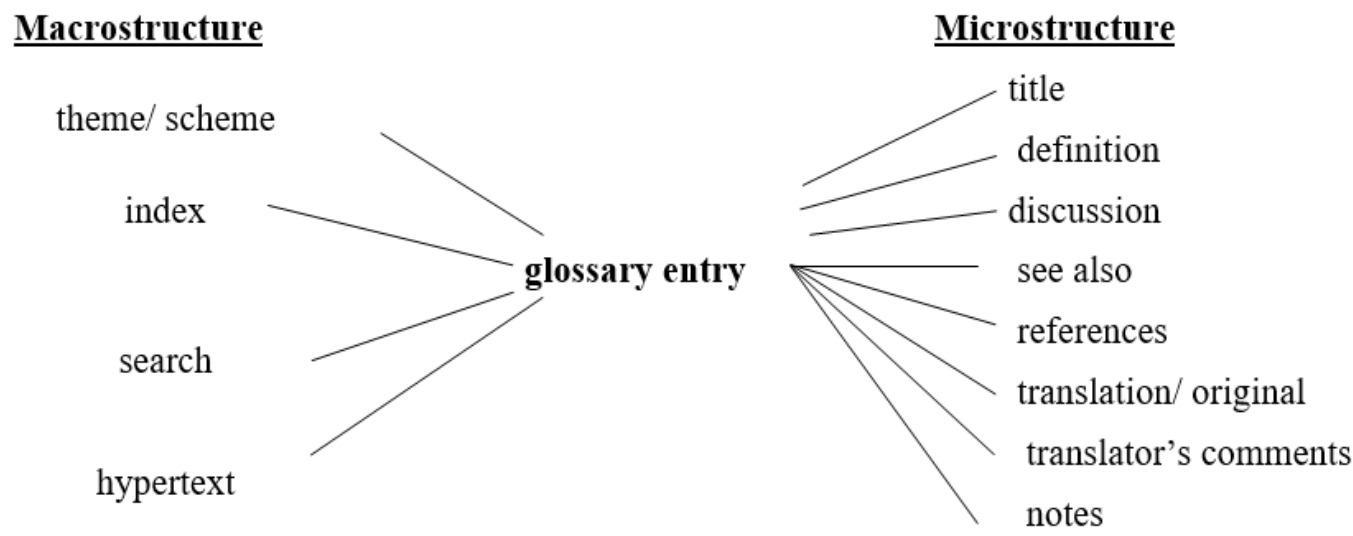

Figure 1 - Model of the bilingual fire science glossary 

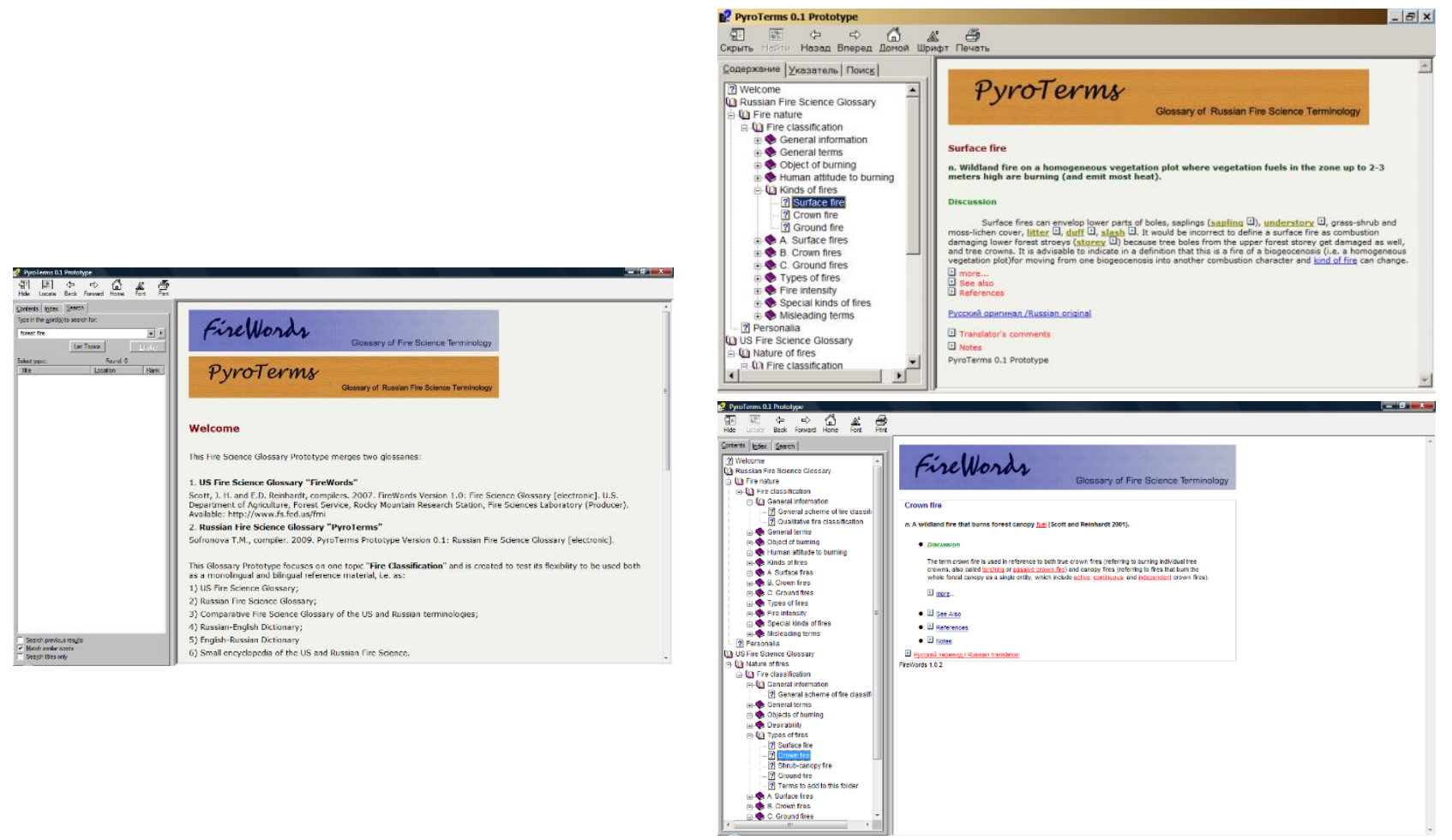

Figure 2 - Interface of the bilingual fire science glossary prototypey

\section{Research Programme}

The proposed project of qualitative nature involves: 1) consultations and workshops with terminology experts from the ATILF Laboratory (Nancy Cedex) and INALCO (Paris) on issues of modern bilingual and multilingual terminological lexicography as well as business trips (funds permitting) or video conferencing with terminology experts from other countries (Finland, the USA); 2) analysis of published works on modern foreign research and technology in this field; 3) creation of fire science corpora on the basis of the Fire Research Institute Library (on the example of English and Russian languages) for extraction of scientific terms and their contextual meanings that have emerged over the past 40-50 years, i.e. during the period of existence of the fire science as an independent field of scientific knowledge; distribution of the terms among the main fire science subfields and in the logical-conceptual schemes: 4) learning the basics of a network approach and programming of network lexicographical products with the specified parameters for the development of an updated software for a multilingual network resource on fire science terminology; 5) interaction with international organizations and foundations potentially interested in the proposed project on development of a multilingual network for a fire science dictionary (e.g., Global Fire Monitoring Center, Germany; FAO, Italy; International Association of Wildland Fires, USA; World Bank, USA); 6) preparation of the necessary documents for implementation of an international project on creation of this multilingual network resource; 7) development of a demo version of a specialized website on the dictionary project with information about the status of work, the latest updates and lexicographical products available for download.

Our terminology institutions and contacts include:

Hosting institution: ATILF CNRS Laboratory (Nancy, France), Prof. Alain Polguère, alain.polguere@univ-lorraine.fr

Partnership Institution: INALCO (Paris, France), Prof. Svetlana G. Krylosova, svetlana.krylosova@inalco.fr 
International contacts:

University of Tampere / University of Helsinki (Finland), Prof. Igor. S. Kudashev, Igor.Kudashev@staff.uta.fi

Kent State University (Ohio, USA), the Institute of Applied Linguistics at the Department of Studies of Modern and Classical Languages, Professors Sue Ellen Wright, swright@kent.edu.

\section{References}

Bobunov AM (2012) Contrastive dictionary of the English language and Russian folk songs as the basis of cross-cultural studies. (Voronezh)

European Glossary for Wildfires and Forest Fires (2012). URL: http://www.fire.unifreiburg.de/literature/EUFOFINET-Fire-Glossary.pdf

FAO / GFMC Wildland Fire Management Terminology (2003) URL: http://www.fire.unifreiburg.de/literature/glossary.htm.

Filipchuk AN (Ed) (2002) 'Forestry: Terminological dictionary.' (VNIILM: Moscow)

Glossary of wildland fire management terms used in the United States (1990) (Society of American Foresters)

Glossary of wildland fire terminology (2007) (National Wildfire Coordinating Group Incident Operations Standards Working Team). URL: http://wwwnwcg.gov.

Helms A (Ed.) (1998) 'The Dictionary of Forestry.' (The Society of American Foresters: Bethesda, MD)

International multilingual fire management terminology (English - Russian - Mongolian - German). Center for Global Fire Monitoring. URL: http://www.fire.uni-freiburg.de/literature/RUS-MONGER-ENG-Glossary-Web.pdf

Kudashev IS (2007) 'Development of translation dictionaries for specialized vocabulary.' (Helsinki University Print: Helsinki)

Kuhn TS (1962) 'The Structure of Scientific Revolutions.' (Univ. of Chicago Pr.: Chicago)

Kurbatsky NP (1972) Terminology of forest fire science. In 'Forest fire science issues'. pp. 171-231. (ILiD SB RAS: Krasnoyarsk)

Mozhaev DV, Novikov B, Rybakov DM (Eds) (1998) 'English-Russian and Russian-English Dictionary of Forestry.' (Moscow: Rousseau, 1998. 857 p.

Rodin SA, Filipchuk AN (2006) 'Encyclopedia of Forestry.' (VNIILM: Moscow)

Scott JH, Reinhardt ED (compilers) (2007) FireWords Version 1.0: Fire Science Glossary [electronic]. U.S. Department of Agriculture, Forest Service, Rocky Mountain Research Station, Fire Sciences Laboratory (Producer). URL: http://www.firewords.net/.

Sofronova TM (2008) Formation of fire science sub-language in the aspect of its history. In: Proceedings of the VI International Scientific Conference on comparative historical linguistics on Language contacts in the aspect of history, 29-31 January 2008 Moscow. pp. 101-102. (Lomonosov Moscow State University: Moscow)

Sofronova TM (2010) Harmonisation of fire science terminology in Russian and English languages. In: Proceedings of the II International Symposium on Terminology and knowledge (Moscow, May, 21 - 22, 2010). pp. 343-351. (Azbukovnik: Moscow)

Sofronova TM (2012) Prototype of bilingual fire science glossary: Version 1.0. Krasnoyarsk: Siberian Federal University (CD). State registration number 0321201925. - ISBN 978-5-7638-2578-7.

Sofronova TM, Felde OV (2017) 'Lexicographical modeling of Russian and English fire science terminology.' (Siberian Federal University: Krasnoyarsk) 
Sternin IA (1992) National specificity of the word notion and lexicography. In 'Contemporary problems of lexicography' (Ed. Dubichinskiy VV, Vakulenko SV, Danilenko AI). pp. 214-216. (Kharkov University: Kharkov)

Sternin IA (2007) 'Contrastive studies and contrastive dictionaries.' (Voronezh State University: Voronezh)

Tabanakova VD, Sotnikova TV, Antonova SN, et al. (Eds) (2009) 'Linguistic modeling.' (Vector Book: Tyumen) 